\title{
Maintaining attributes of old-growth forests in coastal B.C. through variable retention ${ }^{1}$
}

\author{
by W.J. Beese ${ }^{2}$, B.G. Dunsworth ${ }^{3}$, K. Zielke ${ }^{4}$ and B. Bancroft ${ }^{5}$
}

\begin{abstract}
Variable retention is a new approach to harvesting and silvicultural systems that was developed by ecologists in the Pacific Northwest region of North America to address a wide array of forest management goals. Variable retention recognizes that natural disturbances, such as fire, wind or disease, nearly always leave some standing structure from the original forest. This structural complexity plays an important role in forest ecosystem function and biological diversity. A new "retention silvicultural system" was defined that leaves trees distributed throughout harvested areas. This system facilitates retention of structural features of old-growth forests, such as live and dead trees of varying sizes, multiple canopy layers, and coarse woody debris. Weyerhaeuser's British Columbia Coastal Group will use the variable retention approach for all harvesting by 2003 . More than $75 \%$ of the company's coastal harvesting in British Columbia used variable retention in 2001. Company guidelines describe the amount, type, and spatial distribution of retention for groups and individual trees. An adaptive management program is monitoring the amount and type of structural attributes retained in relation to the original forest.
\end{abstract}

Key words: old-growth forests, variable retention, silvicultural systems, biodiversity, landscape zoning

La conservation variable est une nouvelle approche aux systèmes de récolte et de sylviculture que des écologistes de la région du Nord-Ouest du Pacifique, en Amérique du Nord, ont mis au point pour atteindre un vaste ensemble d'objectifs pour l'aménagement forestier. La conservation variable reconnaît que des facteurs naturels de perturbation tels que le feu, le vent ou la maladie laissent presque toujours sur leur passage une structure résiduelle de la foret antérieure. Cette complexité structurelle joue un rôle important dans la fonction d'écosystème de la forêt et dans sa diversité biologique. On a défini un nouveau « système sylvicole de conservation » qui laisse subsister des arbres distribués sur les parterres de coupe. Ce système facilite la conservation des caractéristiques structurales des vieilles forêts telles que des arbres vivants et morts de tailles variables, des étages multiples du couvert et des débris ligneux grossiers. Chez Weyerhaeuser, le groupe « BC Coastal» appliquera cette approche à toute la récolte, dès 2003 . Pour plus de $75 \%$ de la récolte pratiquée dans la zone côtière de la Colombie-Britannique, cette société employait la conservation variable en 2001. Les lignes directrices que s'est données la compagnie décrivent, pour des groupes d'arbres et des arbres individuels, la quantité, le type et la répartition spatiale de la conservation. Un programme d'aménagement adaptatif permet de contrôler la quantité et le type de caractères structuraux conservés relativement à ceux de la forêt antérieure.

Mots clés : vieilles forêts, rétention variable, régimes sylvicoles, zonage par paysage

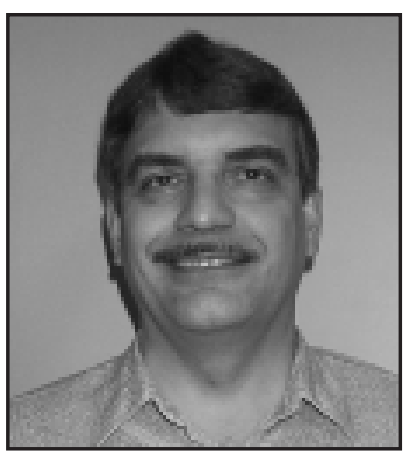

W.J. Beese

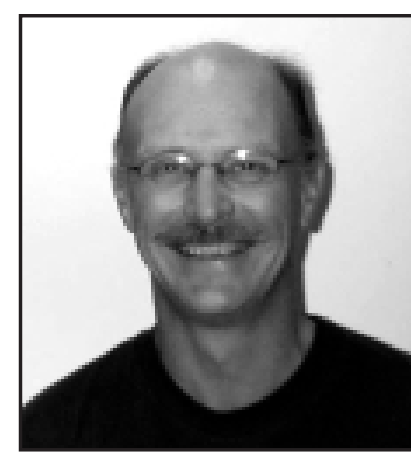

B.G. Dunsworth

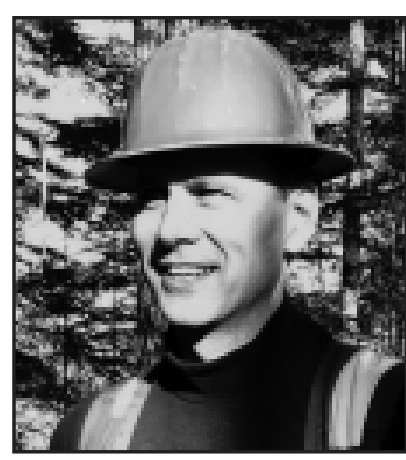

K. Zielke

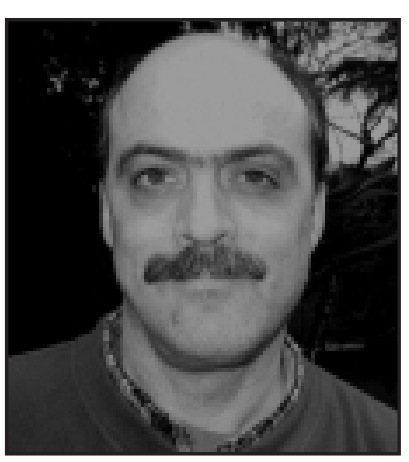

B. Bancroft

\section{Background}

British Columbia (B.C.) has large areas of primary or "oldgrowth" forest, including the largest undeveloped temperate rainforests in the world (see MacKinnon 2003). Most of these forests have infrequent or rare stand-initiating events such as fire or windthrow. Because of the relatively short history of largescale forest harvesting in B.C., the province depends on oldgrowth forests to provide a major source of economic revenue. Clearcutting has been the dominant harvest method in coastal B.C. to date. Both clearcutting and old-growth conservation have 
been persistent social concerns for a number of years. Because of increasing pressure in the European and U.S. marketplaces, customers are demanding higher environmental standards and independent certification of forest practices. In response, the B.C. government consolidated and improved provisions to protect a wide range of resource values on forest lands in the Forest Practices Code of B.C. Act (Province of British Columbia 1994). Government guidelines contain specific targets for both landscape-level and stand-level conservation of oldgrowth habitat in commercial forestry operations on public land. Provided that conservation objectives and rate-of-cut constraints are met, clearcuts of up to 40 ha are allowed in B.C. coastal forests. Despite these provisions, B.C. companies risk losing their "social license" to continue clearcutting old growth. Although there are site conditions and specific geographical areas where alternatives to clearcutting are mandated (e.g., Clayoquot Scientific Panel 1995), we have very little experience in using other silvicultural systems in the old-growth forests of the Pacific coast. Although experience from other regions of the world is relevant, new approaches are needed in order to meet the wide range of values expected from B.C. forests.

In November 1997, the Chief Executive Officer of MacMillan Bloedel (which became part of Weyerhaeuser in 1999) commissioned a comprehensive review of the company's forest policies in its coastal B.C. operations. A group of specialists known as the "Forest Project" team developed a forest stewardship program that was announced publicly in June 1998. The key elements of the program are to define broad management objectives for landscape zones, phase in an ecologically based approach to harvesting and silvicultural systems known as variable retention, increase conservation of oldgrowth forests, and achieve independent forest certification. Weyerhaeuser has since been implementing this program in its coastal B.C. operations.

\section{Biodiversity Conservation}

Loss of species and ecological diversity has become a global concern, arising from the rapid pace of human development and the increasing scarcity of wild places and creatures. The term "biodiversity" is relatively new, but the theory that diversity and stability in ecological systems are related has been debated for decades. The modification of natural landscapes is at the centre of controversy in countries that harvest primary forests. Although activist groups have been the catalyst for change, we believe they reflect a broader societal desire to derive more from forests than timber management and "multiple use" have provided in the past. Fear of losing things irreplaceable_-species, wild places, future options - fuels these desires. Scientific studies over the past few decades also provide evidence that simplifying forest ecosystems at a variety of scales with traditional forestry can reduce biological diversity and create uncertain or unintended consequences for long-term forest functions. Our strategy for conservation of biological diversity includes large protected areas and reserves, landscape zoning, and forest management practices that maintain a diversity of forest structures.

\section{Protected areas}

British Columbia has achieved the government's goal to complete a parks and wilderness system representing at least $12 \%$ of the province. Over $12.3 \%$ of B.C. is currently protected in 11.7 million ha of parks, recreation areas, and ecological reserves (Province of British Columbia 2001). Of B.C.'s 25 million ha of old-growth forest, about 4 million ha is protected in its parks and wilderness system. Outside of parks, an additional 11.5 million ha of old growth will likely remain unharvested in areas that are reserved for wildlife habitat conservation, riparian buffers, slope protection, and old-growth management (Province of British Columbia 2001). British Columbia contains about 7.5 million ha of temperate rainforests, over half of which is considered old growth. Parks include about 715000 ha of temperate rainforest, including the 321 000-ha Kitlope Valley, the largest protected intact coastal temperate rainforest in the world. Other protected areas will be declared as landuse planning processes, underway in B.C. at landscape and regional scales, set broad objectives for management and identify important resource values. Both technological solutions, such as the use of GIS and modelling, and cooperation among landowners and communities are necessary for successful landscape planning and conservation.

\section{Landscape zoning}

With so many competing demands on forests, it is impractical to try to meet all objectives in every area. Objectives such as maintenance of biological diversity must be met on a regional scale. It is not possible to provide habitat for all organisms on the same hectare, or even in the same landscape. Applying the concept of "zoning" can help achieve regional objectives for conservation by assigning different goals to distinct landscape units. Zoning can also help concentrate commercial harvesting activities, minimizing roads and optimizing economic returns. The B.C. government has used zoning to set low, intermediate, and high biodiversity conservation emphasis on public land throughout the province (Province of British Columbia 1995). Our company developed a zoning strategy that we will use to meet various landscape objectives.

After consultation with government and stakeholders, Weyerhaeuser's coastal B.C. tenures were divided into three stewardship zones named Timber, Habitat, and Old Growth. The objective in the Timber Zone is to concentrate on commercial forestry, while protecting water quality, soil productivity, and critical wildlife habitat. The Habitat Zone emphasizes conservation of a broad range of wildlife habitat by maintaining a variety of stand structures. The Old Growth Zone objective is to conserve old-growth forests and associated species in landscapes with a high percentage of undeveloped area, combined with uneven-aged stand management to maintain late-successional forest attributes. The proportion of the landbase in each zone was not based on a rigorous scientific analysis but on expert opinion of what would constitute a balance of ecological and economic objectives.

Zoning was applied to large landscape units (5000 to 50000 hectares) based on the development history and unique ecological attributes of the area. For example, watersheds with more than $65 \%$ old-growth cover were candidates for the Old Growth Zone, and watersheds with a long history of logging and a high proportion of younger age classes were candidates for the Timber Zone, including most of the company's private land. Areas designated for "low intensity" harvesting or medium to high biodiversity emphasis in government landuse plans were matched to the Habitat Zone. The three zones have different goals for both stand- and landscape-level retention to meet the management emphasis (Table 1). Including landscape-level reserves, our analysis projects that, by using our 
approach, $36 \%$ of the productive forest landbase on the company's coastal B.C. tenures will not be logged. Because of the relatively recent history of logging and infrequent large-scale disturbances, most of these reserves are old growth. Old growth will be reserved in every landscape, but with a greater emphasis on large, intact areas. In areas zoned as Old Growth, more than two-thirds of the old forests in the zone will be conserved; the remaining third will be managed through group selection and irregular shelterwood systems to maintain multiaged stands. Zoning can have significant advantages for maintaining habitat supply for certain groups of wildlife species (Dunsworth and Northway 1998).

\section{Forest management practices}

Although protected areas are critical, the amount that society is willing to set aside may not be adequate for viable populations of some species. Our approach includes a combination of landscape- and stand-level strategies to meet conservation goals, balanced with silviculture, recreation, and economics. Stand-level practices are an important management tool for influencing the landscape between parks and other reserves (Hunter 1990). Managing the landscape between reserves for a greater range of habitat conditions may be essential for some organisms, and may facilitate migration, home range movements or shifts and dispersal of some species (Hunter 1997). The attributes that are targeted for retention are those found in the definition of old growth by Dunster and Dunster (1996): large overstorey trees; multi-layered, multi-species canopy; moderate to high canopy closure; decay features; standing dead trees; abundant downed woody debris; and species representative of the potential natural community. Stand-level retention of latesuccessional forest attributes is particularly relevant to Weyerhaeuser's Crown tenures in coastal B.C., where approximately $50 \%$ of the productive forest landbase is considered old growth (i.e., over 150 years in our inventory, although some stands may not meet a structural definition of old growth). Even with a substantial amount of this area in reserves, the company will be dependent upon old-growth harvesting for at least 25 years. Standlevel retention, therefore, will be an important contribution to biodiversity conservation.

\section{Variable Retention \\ Origins}

The stand-level focus of our ecosystem-based forestry is on retaining attributes that typify old-growth forests through a new approach called "variable retention" (VR). This term was first introduced by the Clayoquot Scientific Panel (1995), and was subsequently described in a broader context by Franklin et al. (1997). It was developed by ecologists in the Pacific Northwest region of North America to address a wide array of forest management goals as an alternative to conventional systems that focus on the regeneration and growth of trees. The Weyerhaeuser Company adopted the terminology to refer to any silvicultural system that leaves long-term tree retention. Variable retention is an approach to silvicultural systems and forest harvesting in which structural elements of the existing stand are retained throughout a harvested area for the long term (i.e., at least the next rotation) to achieve specific objectives.

Variable retention recognizes that natural disturbances such as fire, wind or disease nearly always leave some standing structure from the original forest. This structural complexity and its distribution play an important role in forest ecosystem function and biological diversity (Bunnell et al. 1998). Various levels of retention can be used with different types, amounts, and spatial patterns of structure. Retention can be dispersed throughout a cutblock (individual trees or small groups) or aggregated (larger groups) depending upon the objectives. The specific objectives for retention are to:

- retain late-successional forest structures to enrich the diversity of second-growth stands, enhance habitat connectivity over the landscape, and provide "lifeboats" for survival and dispersal of species after harvesting (Franklin et al. 1997);

- create opportunities to match harvesting with market demand without high-grading, or compromising forest health, vigour, genetics, or timber quality;

- match a wide range of retention and silvicultural systems to site-specific regeneration and wildlife needs; and

- meet social expectations of stewardship and visual aesthetics. The rationale for VR can be applied to all ages of forest and a wide range of species to maintain greater structural diversity after harvesting.

\section{Retention system}

A new "retention silvicultural system" is the primary system used in the VR approach. Why define a new system? Foresters need terminology that reflects the management intent, and none of the existing silvicultural systems adequately describe retention of trees for habitat alone rather than for regeneration purposes. Mitchell and Beese (2002) describe the retention system and its rationale as a silvicultural system. The retention system maintains enough tree canopy to have forest or residual tree influences over the majority of a cut area, and leaves long-term live and dead tree reserves of varying sizes and canopy layers, distributed throughout harvested areas (Fig. 1). The retention system has two variants: group retention and dispersed retention. The two variants may be used in the same cutblock.

The retention system definition is based on ecological rationale that distinguishes it from clearcutting or variations of clearcutting such as "clearcut with reserves." A biological definition of a clearcut is given by Kimmins (1997), as "an area in which the above-ground and below-ground influence of the trees has been removed in more than half the area." Keenan and Kimmins (1993) further state that "the minimum size of opening that constitutes a clear-cut varies with the height of the surrounding forest, and is roughly equal to an area greater than about four tree heights in diameter." The retention system, therefore, must maintain greater than half of the original forest area within the influence of surrounding trees, or trees retained within the harvested area, and create openings that are generally less than four tree heights across to be considered something different from a variation of clearcutting.

Forest or residual tree influence is defined as the biophysical effects of forests or individual trees on the environment of the surrounding land. The degree, type, and distance of influence can vary widely; however, within and adjacent to harvested areas, most forest edge and residual tree influences begin to diminish significantly at distances greater than one tree length from a standing tree, group of trees, or forest edge (Keenan and Kimmins 1993). We recognize that specific influences vary by species, aspect, and slope, and that single trees do not have the same influence as groups or stand edges. The retention system is designed 


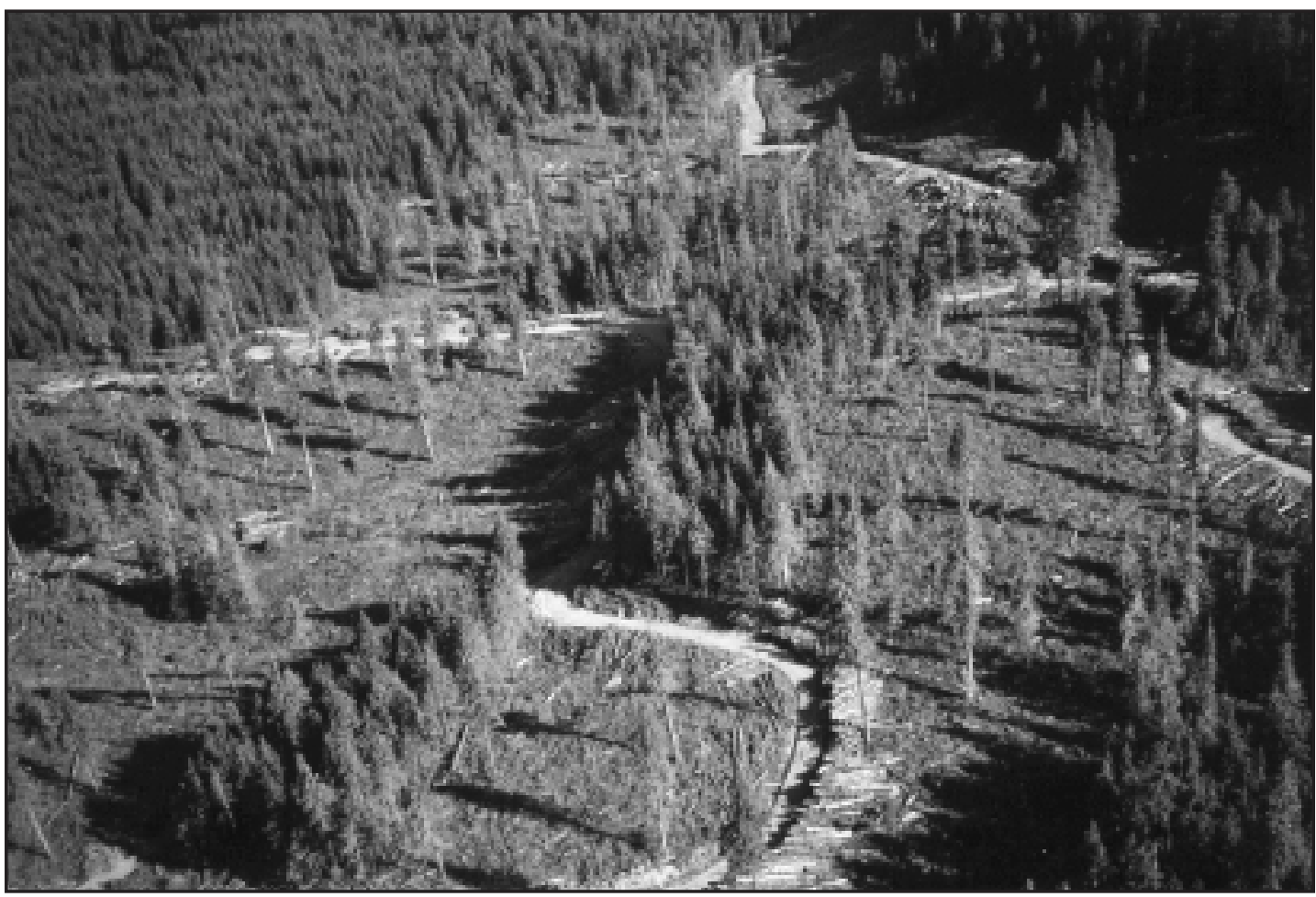

Fig. 1. Retention system harvesting on Vancouver island, B.C. with group and dispersed retention.

to maintain these influences over most of the cutblock area using one codominant tree height as a practical average.

To simplify the operational implementation of the retention system, our company guidelines state that retained groups of trees should be greater than 0.25 ha in size and no more than four tree lengths apart; individual trees or smaller groups should be no more than two tree lengths apart. Consequently, no place within a cutblock is more than two tree lengths from some standing trees. These guidelines are flexible, but they ensure that retention is well distributed within a cutblock and that the forest influence criteria is achieved. The minimum group size ensures that understorey habitat attributes are retained, such as undisturbed shrubs and mosses, and allows retention of dead trees with an unharvested buffer around them for worker safety. Removing large amounts of wood fibre for economic benefit is a necessary compromise in any attempt to model harvesting after natural disturbance. Similarly, we do not propose to denude tens of thousands of hectares at a time despite the precedence for this in nature (e.g., Mount St. Helens eruption, Yellowstone fires, and northern Vancouver Island hurricane windthrow). Within social and economic limits, however, we can do much to retain the forest structures that support the natural diversity of species and ecological functions. Our company guidelines were developed specifically for coastal B.C. conditions; therefore, we advise others to examine their own ecosystems and management objectives to design guidelines for the retention system that fit their forests.

\section{Prescriptions}

Variable retention silvicultural prescriptions must address three important questions: what structures to retain, how much to retain, and what spatial pattern of retention to use (Franklin et al. 1997). The choice of approach depends on both the specific stand-level objectives for retention and how the cutblock contributes to landscape-level management objectives (Fig. 2). Prescriptions must also consider a host of factors, such as safety, ecological values, silviculture, harvesting feasibility, economics, and visual aesthetics. Regeneration of the next stand remains an important objective in the variable retention approach, even though conditions for regeneration and growth may not be optimal when balanced with other resource objectives. Conventional partial-cutting silvicultural systems, such as seed tree, shelterwood, or selection, can also be used in variable retention prescriptions to define the cutting and regeneration strategy but they must also include long-term group or dispersed retention. In these cases, the modifier "with reserves" is added to the name (e.g., group selection with reserves). Where traditional terminology does not apply, the "retention system" best describes the goals of variable retention.

Once objectives are established, the task of determining what structures to retain starts with a field inventory. The attributes of old-growth forests and distribution of certain features can be extremely variable. Our approach is to conduct a reconnaissance survey of a proposed cutblock to map the location of biological control points or "anchors." These consist of key features that are important for meeting either specific or broad goals for retention. Biological anchors may include: riparian areas or rock outcrops; dead standing trees (snags), trees with decay features, coarse woody debris; patches of live trees representing a range of tree sizes, species, and multiple canopy layers; large "veteran" trees, and trees with dens or nests; gullies, seeps, and other unique flora or terrain features. Capturing rare features, ensuring representation or meeting requirements for species of concern may all influence what to retain. 


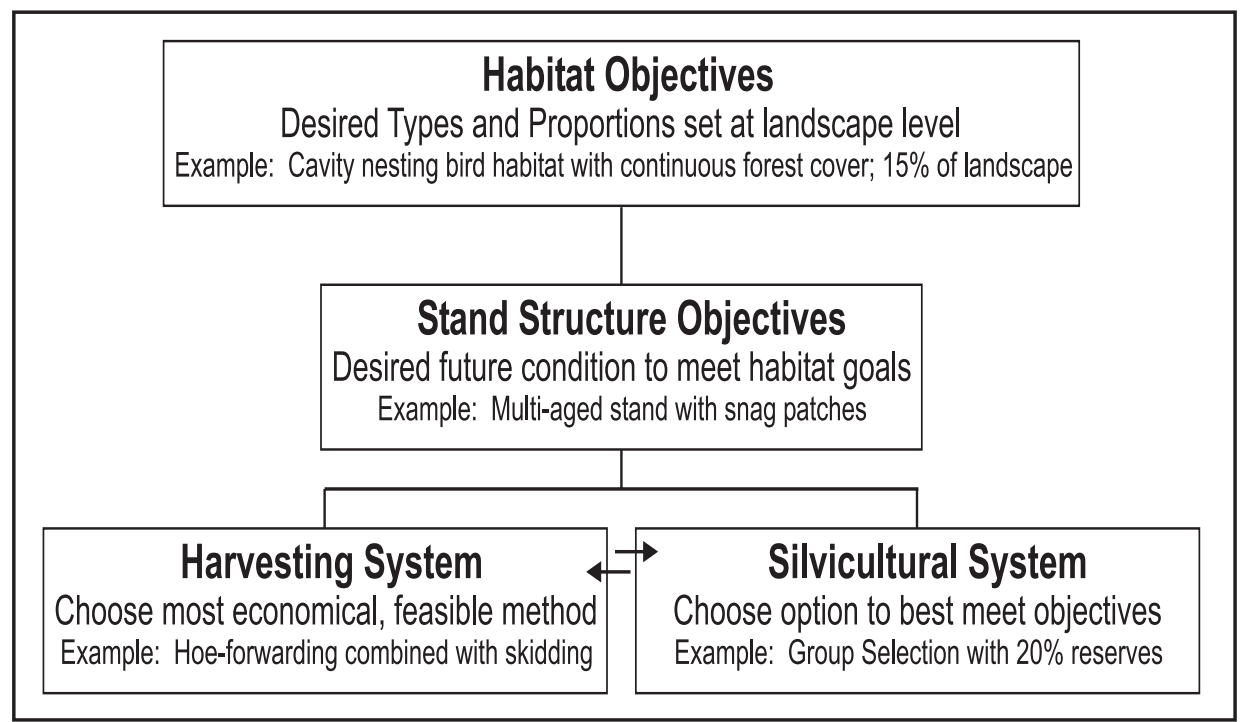

Fig. 2. Relationship between habitat objectives, stand structure, and choice of silviculture and harvesting systems.
The question of how much to retain is a more difficult one. Ultimately, the choice is a compromise between ecological, social, and economic values. How much retention is prescribed at the stand level should take into account the amount of landscapelevel reserves, historical disturbance patterns, and management objectives. We established minimum retention levels within cutblock boundaries ranging from 5 to $20 \%$ depending on the management emphasis and pattern of retention in different landscape zones (Table 1). Monitoring will be conducted to determine whether or not goals are being met.

The spatial pattern of retention can be dispersed (individual trees), aggregated (groups), or a combination of the two. It is more important to retain key attributes than to achieve uniformity in distribution. Weyerhaeuser's approach to VR emphasizes groups, because they provide both ecological and economic advantages (Franklin et al. 1997, Bunnell et al. 1999). For most logging operations, it is easier and safer to retain a variety of old-forest attributes, such as decaying trees, within a group than as dispersed individual trees. Groups also have undisturbed understorey vegetation and forest floor conditions that may be difficult to maintain using dispersed retention (Beese and Bryant 1999).

\section{Harvesting}

Weyerhaeuser has an uncompromising commitment to safety in our introduction of variable retention. Because of the need for increased training and planning, we are implementing our program over five years. The company's goal is to phase in VR by 2003 at a rate of $20 \%$ of total harvested area per year.

\section{Conventional}

Most timber harvesting in Weyerhaeuser's B.C. coastal operations is done with either hoe-forwarding or various cable-yarding systems. Falling is done primarily by hand, although some mechanical falling is done where terrain and stand conditions permit. Hoe-forwarding is the method of choice for yarding timber on gentle slopes because of low cost and reduced ground disturbance compared with skidding. Hydraulic log loaders (called hoes or excavators) with a grapple are used to forward the logs from stump to roadside. Individual logs are lifted, then swung or slid to avoid damage to standing timber. Hoe-forwarding costs can increase with both group and dispersed retention (Phillips 1996).

The most common method of cable harvesting uses a mobile swing yarder equipped with a mechanical grapple. This equipment can be used with a variety of rigging configurations, usually with a mobile backspar. Cable yarding is done on slopes too steep for hoe-forwarding, where helicopter yarding is neither necessary nor cost-effective. Cable systems present the greatest challenge in the design of VR systems and the highest potential increases in costs compared with clearcutting. To avoid these increased costs, most of our harvesting is done with the group retention system rather than uniformly spaced trees. Group retention facilitates yarding by reducing the number of yarding road changes to operate around retained trees.

\section{Helicopter}

Over the past several years, we have increased the proportion of our timber harvesting that is done with the use of helicopters to about $20 \%$. Helicopters reduce or eliminate road building on steep terrain and provide access to forests that would be difficult or impossible to log using conventional cable systems, especially with retention. Most helicopter harvesting is done using a grapple, which substantially reduces both costs and safety hazards compared with the use of ground crews setting chokers. Yarding with helicopters enables a wide range of approaches to VR layout. Recently, company personnel and contractors developed an innovative new technique that we call "standing-stem harvesting" for removing individual stems from a forest by helicopter without felling the tree to the ground. Although standing-stem harvesting will likely be used on only a very small percentage of the landbase, it may prove to be a useful tool for applying selection systems in Old Growth Zone areas.

\section{Economics}

The main economic benefit of VR is maintaining customer acceptance in today's marketplace. The company's experience during the early stages of VR implementation suggests it will be possible to offset some of the additional costs with technolog- 


\begin{tabular}{|c|c|c|c|}
\hline & \multicolumn{3}{|c|}{ Zone } \\
\hline & Timber & Habitat & Old Growth \\
\hline Management emphasis & Commercial timber production & Wildlife habitat conservation & $\begin{array}{l}\text { Maintain late-successional } \\
\text { forest conditions }\end{array}$ \\
\hline Proportion of company-managed landbase in each zone & $65 \%$ & $25 \%$ & $10 \%$ \\
\hline Average proportion of productive forest area in reserves & $28 \%$ & $40 \%$ & $70 \%$ \\
\hline Long-term retention in each cutblock (minimum) & $\begin{array}{l}\text { Dispersed: } 5 \% \\
\text { Group: } 10 \%\end{array}$ & $\begin{array}{l}\text { Dispersed or Group: } 15 \% \\
\text { Retention, Shelterwood, }\end{array}$ & $\begin{array}{l}\text { Dispersed or Group: } 20 \% \\
\text { Selection, Irregular }\end{array}$ \\
\hline Primary silvicultural systems & Retention, Shelterwood & Selection & Shelterwood \\
\hline
\end{tabular}

ical innovation and improved performance. Wherever possible, we will focus harvesting on economic value and retention on ecological value. For biodiversity conservation purposes, some forest structures are better left behind than harvested, so what remains in retention areas need not be fully representative of the original stand. This is a potential win-win situation for both biodiversity and economics. Examples include rock outcrops, talus, forestwetlands, gullies, decayed trees and potential snags.

We expect our annual allowable cut to drop but then stabilize as a result of zoning and variable retention. We also predict some negative impacts on growth and yield from retention and shading; however, with increased emphasis on margin and market value, the overall impact on economics and investment should be positive. Variable retention also addresses many of the costly spatial constraints that govern clearcut harvesting under the B.C. Forest Practices Code, such as cutblock size and deferment of adjacent cutting until regeneration reaches a height of $3 \mathrm{~m}$.

\section{Silviculture \\ Regeneration and growth}

Variable retention presents additional challenges to the forester to achieve regeneration and growth objectives. Although natural seed-in is improved through retention, growth rates of conifers can be reduced by increased shade and moisture competition (Mitchell and Arnott 1995). Weyerhaeuser will continue to use a mixture of both natural regeneration and planting to achieve diverse and valuable stand composition with the VR approach. In coastal B.C., we currently plant more than 8 million seedlings annually on over $90 \%$ of harvested areas using six major species and 12 minor species. On sites that receive abundant western hemlock (Tsuga heterophylla) or amabilis fir (Abies amabilis) natural regeneration, we often fill-plant with other conifers to improve diversity and stand value. We also use genetically improved stock when available.

Because of the predominant use of clearcutting in Pacific coastal forests, there are few empirical studies of the long-term growth impacts of partial cutting. Only recently have experimental comparisons of different retention levels begun in coastal B.C., such as the Montane Alternative Silvicultural Systems (MASS) study (Arnott et al. 1995). We will continue our long-term research and growth and yield programs to improve our knowledge base on fibre yields and forest productivity using partial cutting systems. This includes ongoing research into silvicultural alternatives for management of high-elevation coastal forests (Arnott and Beese 1997). The company is also establishing permanent growth plots in experimental comparisons of retention levels, spatial patterns and cutting cycles.

\section{High-grading}

High-grading is defined as "the removal of the most commercially valuable trees (high-grade trees), often leaving a residual stand composed of trees of poor condition or species composition" (Society of American Foresters 1998). High-grading may have genetic, economic, or stand health implications. The challenge for VR is to define what can be done to leave important habitat diversity, yet avoid the potential negative impacts of such retention on silvicultural practices and economic values.

The dangers of high-grading are: removing the best genetic material for regenerating the next stand, promoting tree species of low commercial value or poor site adaptation, increasing the incidence of disease, or leaving cover of poor quality trees that interferes with the growth of the next stand (Smith 1986). The combination of these factors may lead to degradation of stand quality and growth potential, leaving the forest in a state in which regeneration and growth is poor, and future harvesting is uneconomical. Harvesting must leave the stand in a condition that promotes regeneration of the next stand with healthy trees and sufficient growth potential to meet planned harvest levels, or maintains sufficient volume and quality for profitable stand entries within the rotation. Selection systems must maintain these conditions simultaneously.

Examples of practices that are unacceptable for the retention system and do not avoid the dangers of high-grading include: 1) selection of only the best trees in a stand; 2) single-tree or small-group selection of only one species from a mixed stand, unless cutting is meant to increase stand value (such as selection of poor quality or less valuable species for stand improvement); or 3) leaving dispersed, poor quality trees of sufficient density that they impede the growth of regeneration.

Leaving smaller, less valuable trees, species of lower current market value, or large trees of poor quality does not necessarily lead to silvicultural or economic problems if there is a management strategy to avoid degradation of future stand quality and growth. For example, leaving groups of trees or low densities of dispersed trees throughout a cutblock that are of poor timber quality but high ecological value is acceptable, provided that: 1) regeneration surrounding such patches is composed of healthy seedlings of the desired species through planting or natural regeneration with seed or propagules of high genetic quality or vigorous advance regeneration; 2) the groups are distributed so that there is sufficient growing space for regeneration to meet growth targets, and 3) potential spread of pathogens is dealt with (e.g., dwarf mistletoe or root rot infections). The silvicultural prescription must clear- 
ly state the management goals and the present and future stand treatments necessary to meet the silvicultural objectives.

Traditional definitions of high-grading do not consider the wildlife value of trees that may be considered "poor quality" for silvicultural purposes. At the same time, good quality trees also have ecological value, so retention should not focus exclusively on less valuable trees or patches. Variable retention is not "take the best and leave the rest," nor is it "leave only the best," because we now recognize the important role played by dead and decaying trees for wildlife habitat. Weyerhaeuser's guiding principle in balancing economics and forest health is that we will not compromise long-term forest health, vigour, genetics, or timber quality through our harvesting and silvicultural practices. This ensures that we avoid high-grading and yet maintain old-growth attributes.

\section{Windthrow}

Critical to the success of VR is the design and configuration of cutblocks and stand entries to minimize wind damage. There is potential for negative economic impacts if windthrow is not managed properly. Losses from wind are unavoidable; however, the risks and economic impacts can be managed through planned salvage or retention of downed wood when it meets habitat objectives. Our overall emphasis on group retention should result in far less wind damage than relying on dispersed retention. Although wind damage is hard to predict, the knowledge gained in the past decade will help us design harvesting blocks to minimize its impacts. Multiple stand entries are generally better than a single large removal for minimizing wind damage. Larger trees are often more windfirm in exposed situations. Where serious wind damage occurs, we will salvage the timber, subject to safety and the minimum retention requirements to meet ecological objectives. Our increased use of helicopter grapple yarding should allow us to retrieve small patches of windthrow and individual trees that were uneconomical to salvage in the past. Improving our ability to avoid excessive wind damage is one of the important elements of implementation. A windthrow monitoring strategy is being developed as part of our adaptive management program. This will facilitate feedback to operations and continual improvement of planning. We are also collaborating with the University of British Columbia to develop windthrow hazard prediction models and mapping (Mitchell et al. 2001).

\section{Pathogens}

The main forest health concerns arising from VR for B.C. coastal forests include hemlock dwarf mistletoe, root rot and decay pathogens from stem damage. Once again, an emphasis on group retention helps minimize potential adverse impacts. Our foresters assess stands for mistletoe infection levels and risk when developing silvicultural prescriptions. Where risk is high, we practise lighter levels of group retention; if low, we can use a wider range of approaches, such as group shelterwoods, group selection or dispersed retention. Heavily infected trees along the boundaries of retention can be removed or girdled, creating snags. Marking to remove infected trees in dispersed retention or uniform shelterwoods may reduce overall infection levels.

Logging operations make every effort to avoid stem damage during felling and yarding activities. Where damage is unavoidable, specified rub trees are used during yarding and removed before logging is completed. For sites infected with root rot, the same measures can be taken as with clearcutting such as harvesting the root rot centres and pulling stumps, or reforestation with less susceptible and tolerant tree species. Where it is not possible to leave patches of trees that are free of root rot, tolerant species can be planted in a protective buffer around the patch.

\section{Implementation}

An adaptive management, monitoring, and research program is being developed in support of our implementation of VR. Company biologists have formed partnerships with academic and government scientists to support the program. Monitoring includes both compliance and effectiveness (i.e., did we do what we said we would do, and is it working?). The adaptive management framework for effectiveness monitoring is described in a separate paper in this issue (see Kremsater et al. 2003). This program includes monitoring new VR cutblocks for forest attributes including snags, coarse woody debris, live trees, and stand structure. In the first three years, 204 sites were assessed with 1009 transects and nearly 8000 vegetation plots. Data were collected on over 18000 trees and 48000 pieces of coarse woody debris. The structural work will be used to establish an appropriate sampling design and methodologies.

\section{Implementation monitoring}

Our goal is to phase in VR over five years, increasing the amount by $20 \%$ per year (i.e., $100 \%$ VR in 2003). Variable retention is being used for harvesting in both our second-growth and old-growth forests. We completed 35\% of our harvested area using VR in 1999_our first full year of implementation. In 2000 and 2001, phase-in was completed ahead of schedule in all of our operating areas, with 62 and $75 \%$ VR, respectively. Most importantly, our Timberlands operation continues to lead the industry in coastal B.C. forest operations in safety performance.

Most of the VR cutblocks use the retention silvicultural system, leaving trees in groups (over 0.25 ha in size), or as dispersed individual trees or small groups of a few trees. Most of the VR harvesting in 2001 was done as group retention (44\%) or a combination of groups with some dispersed trees $(27 \%)$. Few cutblocks were done exclusively as dispersed retention (2\%). We used shelterwood and selection systems with reserves for a minor portion of our harvest. Variable retention is being implemented at similar levels in both second-growth and oldgrowth forests.

Multi-pass harvesting was used on $24 \%$ of all cutblocks completed in 2001. The most common use of two or more harvest entries is where a cutblock has adjacency restrictions under the Forest Practices Code that require retention of at least $40 \%$ of the basal area of the stand - a rule designed to prevent progressive clearcutting. An initial harvest is possible in these circumstances, with a second entry after "green-up" height targets are reached on the harvested portion. In other cases, windthrow or visual concerns were the rationale for a two-pass approach.

The average long-term retention level in 2000 and 2001 was over $22 \%$, which includes group and dispersed retention and other reserves (e.g., riparian, wildlife tree patches) within the cutblock boundaries. This is slightly up from the $19 \%$ reported in 1999, and well above the $10 \%$ minimum required for our Timber Zone. A range of retention levels, including both short- and long-term retention, were used in our cutblocks (Fig. 3). About $73 \%$ of the cutblocks left retention in the 


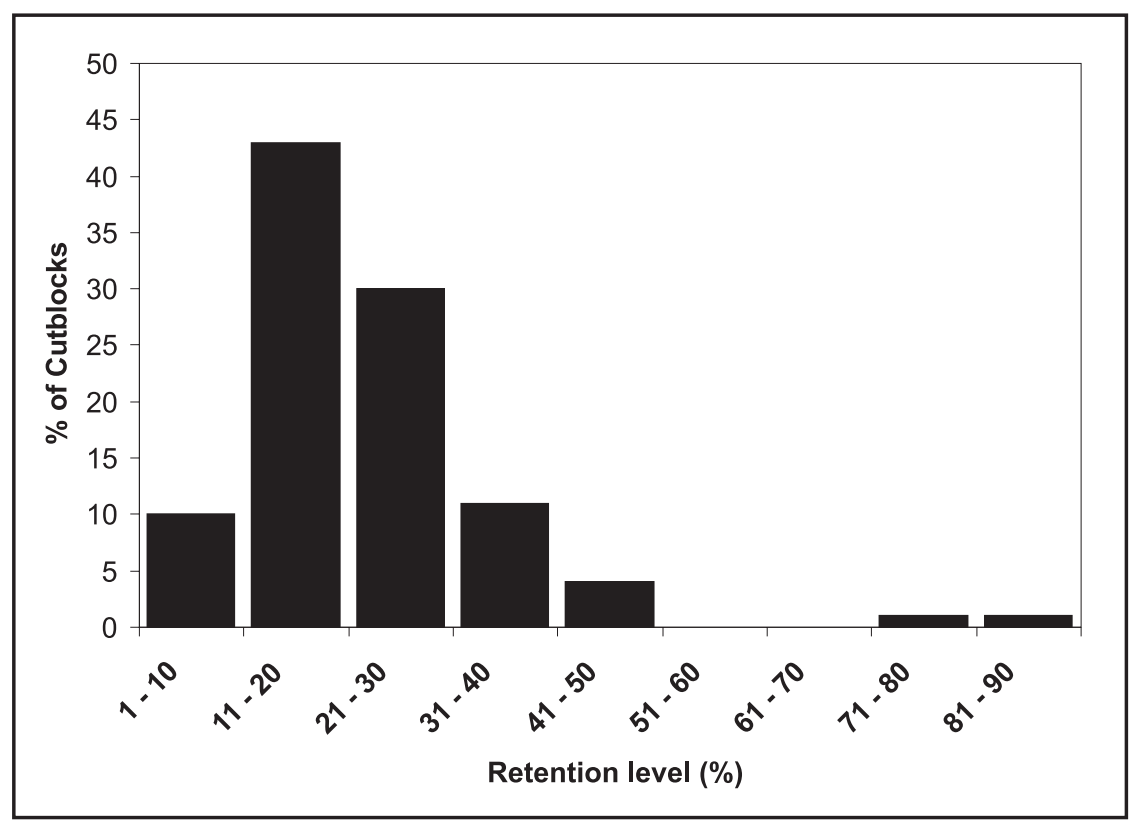

Fig. 3. Proportion of year 2000 cutblocks by retention level.

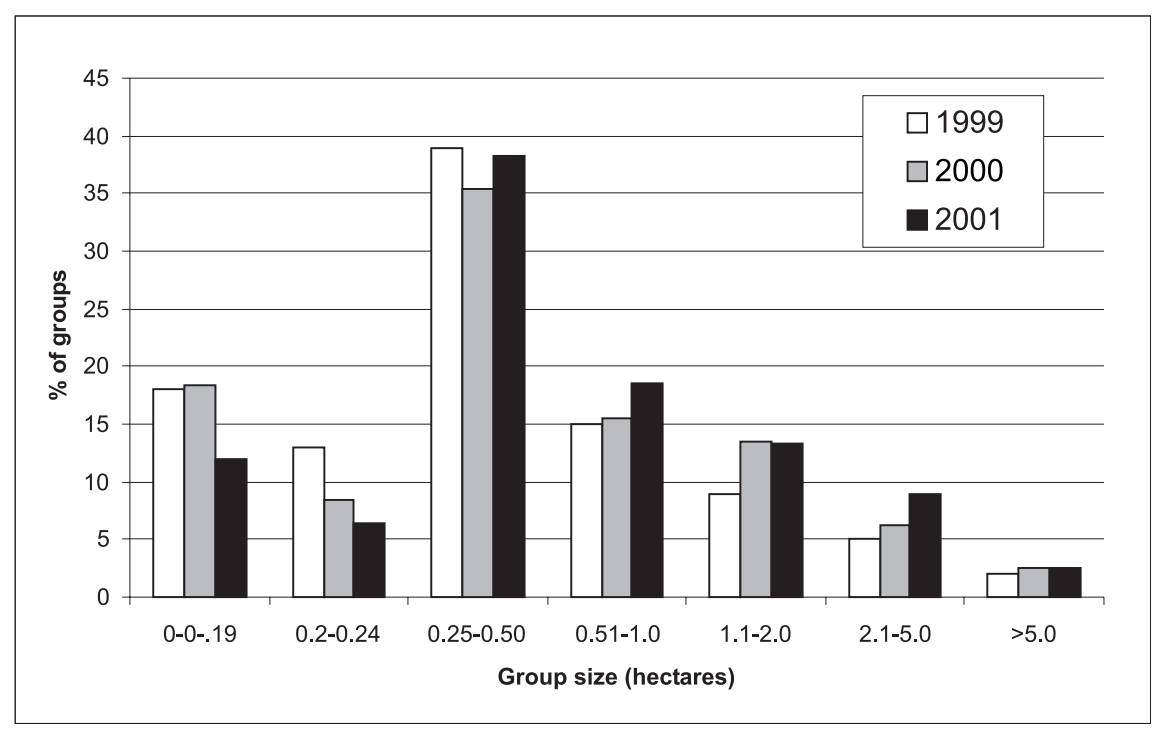

Fig. 4. Distribution of group size for 1113 groups in 154 VR cutblocks (Bancroft and Zielke 2002).

$11-30 \%$ range, with roughly $10 \%$ of blocks at $10 \%$ or less retention, and $15 \%$ in the $31-50 \%$ range. Only $2 \%$ of blocks were over $50 \%$ retention. Our practices show an intentional concentration of retention at the lower end of the range that is designed to maintain structural attributes while attempting to minimize a predicted reduction in growth and yield. We have a sufficient number of cutblocks throughout the 5-50\% range to assess impacts in our monitoring program.

Symmetree Consulting Group completed an evaluation of 154 (4449 ha) VR cutblocks from 1999 to 2001 to monitor performance and identify areas for improvement (Bancroft and Zielke 2002). This represented a $22 \%$ sample of all VR harvesting. Over two-thirds of the blocks were rated as good to excellent examples of VR in relation to company guidelines. Each year, assessments showed improvement in both prescriptions and implementation over the previous evaluation. Key areas for improvement included visual design, marking the potential danger trees and avoiding leave-tree damage.
Symmetree assessed the type of attributes retained in 1113 groups. A range of group sizes was used with an average of 0.9 ha (Fig. 4). Snags occurred in $70 \%$ of the groups in 2001 . When present, groups were "anchored" on special features such as bear dens, nest trees, culturally modified trees, and large veteran trees. Riparian features (35\%), rock outcrops (16\%), and deciduous trees $(11 \%)$ were also used frequently as anchors for retention patches. Retention along small streams that do not require treed buffers under B.C. regulations was assessed along $56 \mathrm{~km}$ of stream length within VR cutblocks. Some retention occurred along 52\% of these streams. Overall, choice of retention was judged subjectively by the inclusion of such features as snags, woody debris, riparian areas, and diverse canopy structure within retention patches. Most of the retention was judged to be of good to optimal choice to provide a range of wildlife habitat (75\% in 1999, 85\% in 2000, and $95 \%$ in 2001), showing improvement each year. We will continue to monitor our performance in order to improve as we gain experience and knowledge. 


\section{References}

Arnott, J.T. and W.J. Beese. 1997. Alternatives to clearcutting in B.C. coastal montane forests. The Forestry Chronicle 73(6): 670-678. Arnott, J.T., W. J. Beese, A.K. Mitchell and J. Peterson (eds.). 1995. Proceedings of Montane Alternative Silviculture Systems (MASS) Workshop, Courtenay, B.C., June 7-8, 1995. Canadian Forest Service and British Columbia Ministry of Forests, Victoria, B.C., FRDA Report 238. 122 p.

Bancroft, B. and K. Zielke. 2002. 2001 Evaluation of variable retention cutblocks. Contract report to Weyerhaeuser, B.C. Coastal Group, Symmetree Consulting Group. 34 p.

Beese, W.J. and A.A. Bryant. 1999. Effect of alternative silvicultural systems on vegetation and bird communities in coastal montane forests of British Columbia, Canada. Forest Ecology and Management 115: 231-242.

Bunnell, F.L., L.L. Kremsater and M. Boyland. 1998. An ecological rationale for changing forest management on MacMillan Bloedel's forest tenure. Contract report to MacMillan Bloedel Ltd. 281 p.

Bunnell, F.L., L.L. Kremsater and E. Wind. 1999. Managing to sustain vertebrate richness in forests of the Pacific Northwest: relationships within stands. Environmental Reviews 7: 97-146.

Clayoquot Scientific Panel, 1995. Scientific Panel for Sustainable Forest Practices in Clayoquot Sound, Report 5, Sustainable ecosystem management in Clayoquot Sound: planning and practices, Victoria, B.C., 296 p.

Dunster, J. and K. Dunster. 1996. Dictionary of natural resource management, University of British Columbia Press, Vancouver, B.C. 363 p.

Dunsworth, B.G. and S.M. Northway. 1998. Spatial assessment of habitat supply and harvest values as a means of evaluating conservation strategies: a case study. In P. Bachmann, M. Köhl and R. Päivinen (eds.). Assessment of Biodiversity for Improved Forest Planning. pp. 315-329. Kluwer Academic Publishers, European Forest Institute Proceedings No. 18.

Franklin, J.F., D.R. Berg, D.A. Thornburgh and J.C. Tappeiner. 1997. Alternative silvicultural approaches to timber harvesting: variable retention harvest systems. In K.A. Kohn and J.F. Franklin (eds.) Creating a forestry for the 21st century: the science of ecosystem management. pp. 111-139. Island Press, Washington, D.C.

Hunter, M.L. Jr., 1990. Wildlife, forests and forestry: principles of managing forests for biological diversity. Prentice Hall, Englewood Cliffs, New Jersey, $370 \mathrm{p}$.
Hunter, M.L. 1997. The biological landscape. In K.A. Kohn and J.F. Franklin (eds.). Creating a forestry for the 21st century: the science of ecosystem management. pp. 57-68. Island Press, Washington, D.C. Kimmins, J.P. 1997. Balancing act: environmental issues in forestry. Second Edition, University of British Columbia Press, Vancouver, British Columbia. 305 p.

Keenan, R.J. and J.P. Kimmins. 1993. The ecological effects of clearcutting. Environmental Reviews 1: 121-144.

Kremsater, L., F. Bunnell, D. Huggard and G. Dunsworth. 2003. Indicators to assess biological diversity: Weyerhaeuser's coastal British Columbia forest project. The Forestry Chronicle 79(3) 590-601.

MacKinnon, A. 2003. West-coast, temperate, old-growth forests. The Forestry Chronicle 79(3) 475-484.

Mitchell, A.K. and J.T. Arnott. 1995. Effects of shade on the morphology and physiology of amabilis fir and western hemlock seedlings. New Forests 10: 79-98.

Mitchell, S.J., T. Hailemariam and Y. Kulis. 2001. Empirical modeling of cutblock edge windthrow risk on Vancouver Island, Canada, using stand level information. Forest Ecology and Management 154: 117-130.

Mitchell, S.J., and W.J. Beese. 2002. The retention system: reconciling variable retention with the principles of silvicultural systems The Forestry Chronicle 78(3): 397-403.

Phillips, E.J. 1996. Comparing silvicultural systems in a coastal montane forest: productivity and cost of harvesting operations. Canadian Forest Service and British Columbia Ministry of Forests, Victoria, B.C., FRDA Report 247. 42 p.

Province of British Columbia. 1994. Forest Practices Code of British Columbia Act. S.B.C., c. 41.

Province of BC. 1995. Biodiversity Guidebook. Forest Practices Code Guidebook, BC Min. Forests, September 1995. http://www.for.gov.bc.ca/tasb/legsregs/fpc/fpcguide/biodiv/biotoc.htm Province of British Columbia. 2001. British Columbia Ministry of Forests Web site. www.growingtogether.ca

Smith, D.M. 1986. The practice of silviculture. 8th edition. John Wiley and Sons. New York, NY, USA. 527 p.

Society of American Foresters. 1998. The dictionary of forestry. J.A Helms (ed.). Society of American Foresters, Bethesda, MD. 210 p. 